Ijtihad: Jurnal Wacana Hukum Islam dan Kemanusiaan

Vol. 19, No. 1 (2019), pp. 103-123, doi : 10.18326/ijtihad.v19i1.103-123

\title{
Telaah ulang wacana haid dan istihädah pada akseptor keluarga berencana
}

\author{
Wahyu Setiawan, Azmi Siradjuddin, Liberty \\ IAIN Metro Lampung \\ E-mail:wahyuiainmetro@gmail.com,azmisiradjuddin1965@gmail.com, libertiibet@gmail.com \\ DOI: 10.18326/ijtihad.v19i1.103-123
}

\begin{abstract}
The legal inference of vaginal blood in Islam generally adopts the paradigm called haid-cum-istihadăh. The paradigm starts with the identification of menstrual blood by looking at minimum limit, maximum limit, or by blood characters. When the blood fails the requirements established by mazhab figh, it turns to the so-termed istihadăh. The paradigm tends to be confusing when confronted with menstrual irregularities that happened on hormonal acceptors. The vaginal blood could not be categorized as menstrual by medical or fiqh literatures. This article offers an alternative paradigm called istibadäh-cumhaid wich is built upon three building blocks namely: turäth interpretation, medical considerations, and empirical experiences of hormonal acceptors. These three building blocks were underpinned by Loay Safi's thought called Unified Approach to Textual and Contextual Analysis. The data of this research were collected through studies on comparative figh literatures and interviews with 70 acceptors, 1 obstetrician-gynecologist, 5 midwifes, and 4 academicians in the field of medication. This alternative paradigm urges that vaginal blood acceptors treated as istihadăh. Next to istihadāh identification, is the establishment of menstruation days for acceptors based on fiqh mazhab related to mustahạdah rules.
\end{abstract}

Penetapan hukum darah pervaginam dalam Islam secara umum menggunakan paradigma yang dapat disebut haid-cum-istỉhadäh. Paradigma ini bertitik tolak pada identifkasi darah haid terlebih dahulu dengan melihat batas minimal, batas maksimal, atau berdasarkan karakter darah. Apabila tidak memenuhi syarat yang telah ditetapkan mazhab fiqh, maka darah disebut sebagai istiḩadăh. Paradigma ini menjadi rancu ketika dihadapkan dengan ketidakteraturan menstruasi yang dialami akseptor KB hormonal. Darah pervaginam yang terjadi tidak dapat disebut sebagai haid baik menurut medis maupun literatur fiqh. Artikel ini menawarkan paradigma alternatif yang disebut istihhadăh-cum-haid. Sebuah paradigma yang merupakan hasil integrasi tiga kutub: interpretasi turäth, keilmuan medis, dan pengalaman empiris akseptor KB hormonal. Dialog ketiga kutub tersebut dibingkai dengan kerangka berpikir Loay Safi yang disebut Unified Approach to Textual and Contextual Analysis. Data 
penelitian ini dikumpulkan melalui kajian kitab-kitab fiqh perbandingan dan wawancara dengan 70 akseptor, 1 dokter spesialis kandungan, 5 bidan, dan 4 praktisi akademik kesehatan. Paradigma alternatif sebagai hasil penelitian ini menyatakan bahwa darah pervaginam pada akseptor langsung ditetapkan sebagai istihadăh. Tahap berikutnya berupa penetapan hari-hari haid bagi akseptor KB berdasar fiqh mazhab terkait ketentuan hukum mustahạdah.

Keywords: menstruation; istihadăh; hormonal contraception; medical-consideration; turäth-interpretation

\section{Pendahuluan}

Pemaduan antara tradisi keilmuan fiqh dengan medis terkait wacana darah pervaginam merupakan keniscayaan. Apalagi ketika dihubungkan dengan pengalaman empiris perempuan akseptor KB hormonal yang mengalami perdarahan abnormal. Keniscayaan ini memiliki legitimasi kuat dari praktik Nabi saw. ketika memberikan solusi bagi perempuan yang meminta jawaban atas permasalah darah pervaginam yang dialami. Praktik Nabi saw. menghapus tabu menstruasi menjadikan wacana darah pervaginam mencuat dalam berbagai literatur hadis.

Ada satu catatan penting dapat dikemukakan bahwa hampir seluruh ketentuan Nabi saw didasarkan pada dan sebagai solusi atas kasus yang terjadi pada perempuan masa itu. 'Ā'ishah, Ummu Salamah, Fatīìmah binti Abī Hubaish, Ummu Habībah, Asmā’ binti ‘Umais, dan Hamnah binti Jahsh - radiyalläh 'anhunna - adalah sebagian nama sahabat perempuan yang berperan dalam kemunculan hadis-hadis haid, nifäs, dan istiḥāạdah. Menariknya, Nabi saw. tidak memberikan jawaban seragam terhadap semua kasus, namun mempertimbangkan kondisi perempuan sebelum memutuskan suatu hukum. Terlihat adanya dialog antara wahyu (putusan Nabi saw.) dengan orang yang menerima takliff (pembebanan hukum). Pola penetapan hukum aplikatif dengan mempertimbangkan kondisi riil perempuan menjadi semangat bagi penyimpulan hukum, termasuk ketentuan haid dan istiḥāạdah ketika dihubungkan dengan penggunaan alat kontrasepsi.

Salah satu efek dari alat kontrasepsi hormonal pada akseptor KB adalah ketidakteraturan siklus menstruasi, lama menstruasi, serta kejadian spoting (insiden bercak darah). Pada sebagian besar akseptor, terjadi insiden bercak darah yang tidak teratur dan dengan kadar sedikit atau perdarahan di luar siklus yang kadang-kadang berkepanjangan (Baziad, 2002: 9; Mahdalena et al., 2014: 184-185). 
Literatur figh sendiri menyatakan bahwa masa perempuan haid paling lama adalah 15 hari pada setiap bulan (al-Nawawī, II, t.t.: 344). Bahkan Misbah (2016: 112) setelah meneliti karya Ibnu Rushd menjelaskan perbedaan ulama terkait batas maksimal dan minimal haid. Batas maksimal menurut Mālik dan al-Shāfici adalah 15 hari. Sementara Abū Ḥanīfah menetapkan 10 hari. Masa minimal haid menurut Mālik tidak terbatas, satu tetes (dufqah wähidah) pun dapat dinyatakan haid. Al-Shāfici mempunyai pandangan berbeda, minimal haid menurutnya adalah satu hari satu malam. Bahkan Abū Ḥanīfah menetapkan tiga hari tiga malam.

Perbedaan tersebut memperlihatkan bahwa produk fiqh merupakan jawaban dari persoalan hukum pada masa figh tersebut ditulis. Telaah ulang penetapan hukum darah pervaginam perlu dilakukan agar tidak bertopang dengan pendekatan normatif-fiqhiyah ansich. Kajian ini kemudian menjadi lebih penting lagi, karena ketetapan haid dan istih ạdah di samping merupakan bagian dari perhatian Islam terhadap persoalan reproduksi perempuan juga berimplikasi terhadap banyak ketentuan agama. Banyak praktik keagamaan yang bersifat kontradiktif terkait penentuan status hukum darah reproduksi ini baik dalam aspek íbädah (seperti ketentuan salat dan puasa) maupun munäkaḥah (kebolehan hubungan seksual).

Berdasarkan masalah tersebut, maka artikel ini bertujuan untuk mengkaji realitas perubahan siklus menstruasi bagi akseptor KB sekaligus cara menetapkan hukum haid dan istihädah pada akseptor KB sebagai produk hukum aplikatif. Deskripsi diawali dengan paparan metode penelitian, survey literature yang relevan sekaligus kerangka teori yang digunakan. Selanjutnya difokuskan pada diskusi tentang realitas perubahan siklus menstruasi akseptor KB, kelemahan paradigma lama, kemudian pengajuan paradigma alternatif yang disebut istihäạda-cum-haid sekaligus aplikasi dalam penetapan hukum darah pervaginam bagi akseptor KB.

\section{Metode penelitian}

Artikel ini merupakan hasil perpaduan antara library research dan penelitian lapangan. Penelitian pustaka diarahkan pada penelaahan kitab-kitab fiqh perbandingan. Ada tiga kitab utama yang digunakan, yaitu: pertama, Bidāyah al-Mujtahid wa Muntahā al-Muqtasid karya Ibn Rushd; kedua, Kitäb al-Fiqh 'alā al-Madhäbib al-Arba'ah karya 'Abd al-Raḥmān al-Jazirīi; dan 
ljtihad: Jurnal Wacana Hukum Islam dan Kemanusiaan, Volume 19, No. 1, Juni 2019: 103-123

ketiga, al-Fiqh al-Islämi wa Adillatuh karya Wahbah al-Zuhaylī. Locus penelitian ini terpusat di Kota Metro, Propinsi Lampung dengan pengumpulan data melalui teknik wawancara dan dokumentasi. Wawancara mendalam dilakukan pada 70 akseptor KB hormonal, 1 spesialis kandungan, 5 bidan, dan 4 akademisi kesehatan. Selanjutnya proses analisis dilakukan dengan analogi dan interpretasi. Analogi berfungsi untuk menghubungkan konsepsi pemikiran fuqahä madhähib dengan keilmuan medis tentang status darah pervaginam. Sedangkan interpretasi dilakukan dengan melakukan pemaknaan atas kontruksi syari'ah serta medis terhadap status darah dari berbagai realitas yang dialami para akseptor KB hormonal dalam situasi alamiah sehingga diperoleh produk hukum yang komprehensif dan aplikatif.

\section{Penelitian terdahulu dan kerangka teori}

Perdebatan akademik terkait masalah darah pervaginam seringkali difokuskan pada relasi gender dalam konsep teologis dengan paham tabu menstruasi. Penelitian tentang kritik teologis terhadap tabu menstruasi dilakukan baik secara komparatif konsepsi agamaagama maupun spesifik menurut Islam (Sigvartsen, 2017) (Noble, 2018) dan (Olusola and Ojo, 2014). Penelitian-penelitian tersebut lebih bermuara pada kajian menstruasi yang dihubungkan dengan konstruk sosial terhadap perempuan.

Kajian terhadap hukum menstruasi secara spesifik lebih banyak mengacu pada kajian karya fiqh klasik dengan pendekatan normatif (Ibrahim, 2016) (Barakah, 2018) dan (Misbah, 2017). Keberanjakan kajian dengan upaya menyandingkan pendekatan fiqh dengan medis terhadap kajian darah pervaginam telah dilakukan, namun lebih terfokus secara konseptual (Abdullah et al., 2019) (Musyafa'ah, 2014) dan (Musyafa'ah, 2016).

Artikel ini berupaya mengisi sebuah lacuna tentang wacana darah reproduksi perempuan dengan fokus kajian pada penetapan status hukum berdasarkan pendekatan figh dan medis dengan memperhatikan realitas yang dialami para akseptor KB dengan menggunakan paradigma integratif. Paradigma integratif adalah sebuah upaya metodologis untuk melengkapi paradigma literalistik-normatif yang menjadikan otoritas teks sebagai landasan berpikir dalam upaya penemuan hukum Islam (Anwar, 2003: 47). Berangkat dari kelemahan paradigma ini diperlukan upaya rekonstruksi kepada paradigma integratif yang menggabungkan wahyu Tuhan dan temuan manusia (holistik-integratif) yang bercorak teo- 
Telaah ulang wacana haid dan istiḥādah pada akseptor keluarga berencana (Wahyu Setiawan, dkk.)

antroposentris dengan meminjam kerangka berpikir yang ditawarkan Louay Safi sebagai Unified Approach to Textual and Contextual Analysis (Safi, 1996: 182) sebagai berikut:

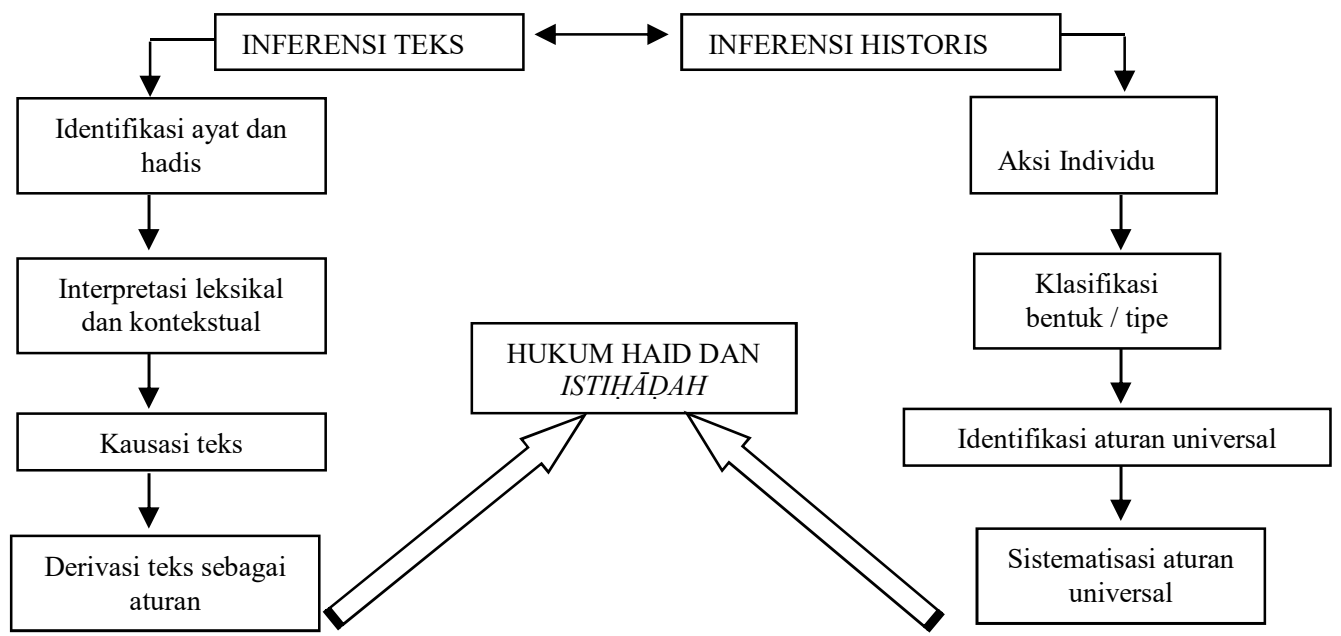

\section{Perubahan siklus menstruasi akseptor KB di Kota Metro}

Akseptor KB menurut data yang dikeluarkan oleh BPS Kota Metro relatif tinggi. Berikut tabel peserta aktif KB dengan perbandingan alat kontrasepsi yang digunakan pada lima kecamatan yang ada di Kota Metro (BPS Kota Metro, 2018: 126).

Tabel 1. Data Peserta KB Aktif di Kota Metro Tahun 2018

\begin{tabular}{lrrrrrrrrr}
\hline \multirow{2}{*}{ Kecamatan } & Jumlah & \multicolumn{7}{c}{ Peserta KB Aktif } \\
\cline { 3 - 10 } & PUS & IUD & MOW & MOP & Kn & Implant & Suntik & Pil & Jumlah \\
\hline Metro Selatan & 2.741 & 604 & 4 & 0 & 4 & 220 & 1.021 & 604 & 2.457 \\
Metro Barat & 5.737 & 703 & 6 & 2 & 10 & 725 & 1.647 & 702 & 3.795 \\
Metro Timur & 8.074 & 536 & 139 & 15 & 25 & 503 & 2.386 & 780 & 4.384 \\
Metro Pusat & 9.269 & 996 & 153 & 39 & 12 & 1.343 & 3.170 & 1.559 & 7.272 \\
Metro Utara & 3.515 & 196 & 4 & 0 & 6 & 680 & 2.284 & 1.072 & 4.242 \\
\hline Total & 29.336 & 3035 & 306 & 56 & 57 & 3.471 & 10.508 & 4.717 & 22.150 \\
\hline
\end{tabular}

Sumber: Kota Metro Dalam Angkea 2018

IUD: Intra Uterine Device

MOW: Medis Operatif Wanita; tubektomi

MOP: Medis Operatif Pria; vasektomi

$\mathrm{Kn}$ : Kondom 
ljtihad: Jurnal Wacana Hukum Islam dan Kemanusiaan, Volume 19, No. 1, Juni 2019: 103-123

Akseptor KB aktif di Kota Metro menurut Data BPS Tahun 2018 mencapai 22.150 orang. Jumlah ini apabila dibandingkan dengan pasangan usia subur yaitu 29.336 maka akseptor KB aktif mencapai $75.5 \%$. Dari total akseptor KB menurut data tersebut, maka perbandingan penggunaan $\mathrm{KB}$ hormonal dengan non-hormonal cukup tinggi. Berikut ditampilkan data perbandingan tersebut.

Gambar 1.

\section{Grafik Perbandingan Peserta KB Hormonal dan Non-Hormonal Tahun 2018}

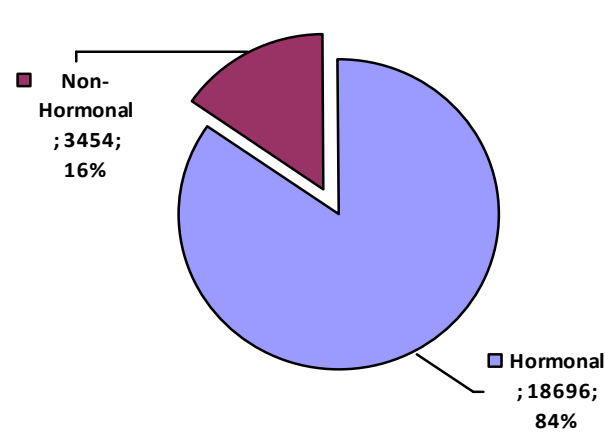

Grafik 1. Perbandingan Alat Kontrasepsi

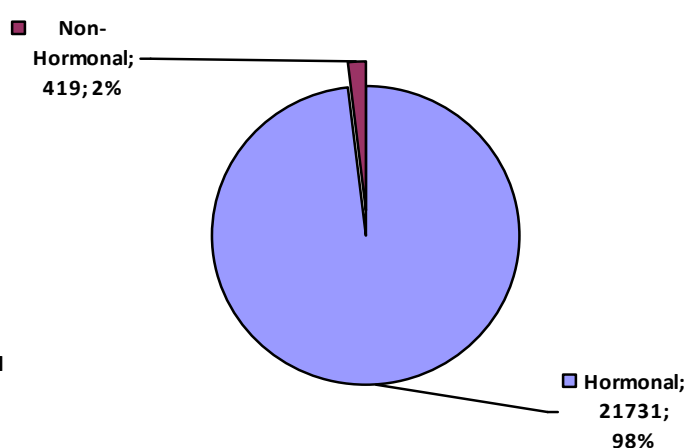

Grafik 2. Perbandingan Alat Kontrasepsi

Data perbandingan penggunaan KB hormonal dengan non-hormonal pada grafik 1 dengan asumsi bahwa akseptor IUD tidak diklasifikasikan sebagai kontrasepsi hormonal. Padahal penggunaan IUD saat ini lebih banyak yang mengandung unsur hormon progesteron yang notabene sebagai kontrasepsi hormonal suntik (Yuliawati, wawancara, 10 Oktober 2019). Apabila asumsi ini dimasukkan dalam perbandingan tersebut seperti yang diperlihatkan Grafik 2, maka dapat dinyatakan bahwa pengguna kontrasepsi hormonal mencapai 98\% dari akseptor aktif yang ada di Kota Metro.

Alat kontrasepsi hormonal secara umum mencakup semua alat kontrasepsi yang mengandung hormon progesteron buatan yang disebut progestin dan hormon estrogen. Satu alat kontrasepsi dapat mencakup kedua hormon atau hanya progesteron saja. Sebagai progesteron sintetik (progestin) seperti pada kontrasepsi suntik yang paling banyak digunakan para akseptor KB maka efek samping sangat dimungkinkan terjadi. 
Progestin tidak persis sama dengan progesteron yang diproduksi secara alamiah oleh tubuh perempuan, maka disebut Depot Medroxy Progesteron Asetat (DMPA). Efek samping dari penggunaan DMPA adalah munculnya spoting (flek) pada saat menggunakan kontrasepsi suntik (Yuliawati, wawancara, 10 Oktober 2019).

Penelitian ini selanjutnya lebih memfokuskan pada akseptor KB hormonal aktif yang mengalami ketidakteraturan siklus menstruasi, kejadian spoting, maupun perubahan lama dan jumlah darah menstruasi yang dialami. Klasifikasi terhadap perubahan menstruasi yang dialami oleh akseptor KB hormonal dapat menggunakan pola yang telah ditetapkan secara medis. Menstruasi yang dialami perempuan dilihat dari dua sudut pandang, yaitu: pertama, siklus menstruasi yaitu jarak waktu antara menstruasi pertama dengan berikutnya; kedua, jumlah darah dan lamanya menstruasi yang dialami. Kedua sudut pandang dalam klasifikasi menstruasi dapat dilihat pada bagan berikut:
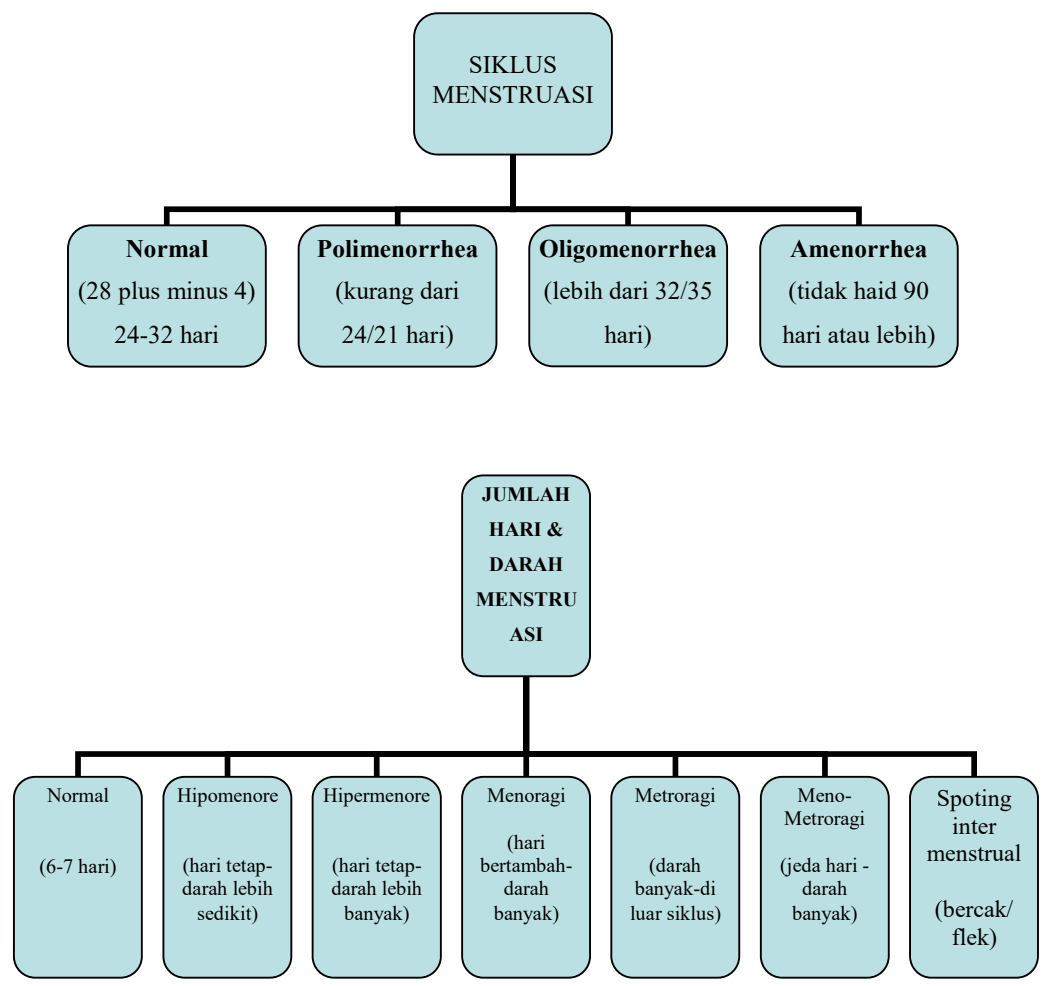
ljtihad: Jurnal Wacana Hukum Islam dan Kemanusiaan, Volume 19, No. 1, Juni 2019: 103-123

Berdasarkan klasifikasi tersebut, kasus-kasus yang dialami akseptor KB hormonal sebagai berikut: pertama, adanya spoting atau flek yang keluar sebelum adanya darah maupun setelah darah. Kejadian ini sangat umum terjadi dengan jumlah hari yang bervariasi. Spoting yang terjadi sebelum keluarnya darah ada yang lima hari bahkan satu minggu (Ani dan Nisa [bukan nama sebenarnya], wawancara, 15 September 2019). Begitu juga spoting yang terjadi setelah darah terhenti. Pada kasus ini, keluhan yang dirasakan adalah spoting dengan jumlah hari yang relatif panjang yaitu 10 hari atau bahkan lebih (Suti, Rika, dan Ira [bukan nama sebenarnya], wawancara, 15 september 2019). Akumulasi dari seluruh hari spoting dan keluarnya darah yang dialami rata-rata melebihi 15 hari;

Kedua, spoting selama tiga bulan namun ada jeda bersih selama kurang lebih lima hari pada tiap bulannya (Widi [bukan nama sebenarnya] akseptor implan, wawancara, 10 September 2019);

Ketiga, keluar darah dari hari pertama hingga hari ke-15. Setelah berhenti darah, terkadang keluar flek, cairan berwarna keruh, dan terkadang darah kembali (Rita [bukan nama sebenarnya] akseptor IUD, wawancara, 10 September 2019);

Keempat, selama dua bulan berturut-turut tidak keluar darah, namun pada bulan ketiga mengalami perdarahan hingga kurang lebih 20 hari (Uni, Nia, Ria [bukan nama sebenarnya] akseptor suntik, wawancara, 10 September 2019);

Kelima, keluar darah selama seminggu dalam jumlah lebih banyak dari sebelum pemakaian kontrasepsi. Setelah suci kurang lebih seminggu, kembali keluar darah serupa dalam waktu kurang lebih lima hari yang diakhiri flek dalam waktu beberapa hari (Ina [bukan nama sebenarnya] akseptor IUD, wawancara, 19 September 2019);

Keenam, keluar darah yang terputus-putus atau ada jeda antara darah dengan suci. Pada kasus ini akseptor menyampaikan bahwa dia mengalami perdarahan selama kurang lebih tiga hari, tiga hari berikutnya berhenti, hari ketujuh kembali keluar darah (Dewi, Rina, Nisa, Heni [bukan nama sebenarnya] akseptor suntik, wawancara, 19 September 2019).

Dari beberapa kasus yang dialami oleh akseptor KB hormonal pada masa awal penggunaan alat kontrasepsi beragam, baik pada perubahan siklus maupun jumlah hari dan darah menstruasi yang dialami. Terlihat bahwa perubahan pola menstruasi yang dialami lebih dominan pada kejadian spoting. Selain spoting, pada penggunaan awal kontrasepsi, 
kejadian hipermenore, menoragi, meno-metroragi, bahkan metroragi banyak dialami oleh akseptor KB hormonal terutama suntik, IUD, dan implan. Semakin lama pemakaian, yaitu lebih dari satu tahun, maka kejadian spoting semakin menurun bahkan pada akseptor suntik lebih banyak mengalami amenore, yaitu terputus haid sama sekali. Hal ini diakui oleh pihak medis sebagai efek dari semakin menipisnya dinding endometrium disebabkan progestin pada kontrasepsi suntik yang menyebabkan progesteron tidak pernah turun, tetapi stabil bahkan dapat meningkat (Rosnilam, wawancara, 20 September 2019).

\section{Sudut pandang hukum dalam penetapan status darah akseptor KB hormonal}

Ibn Rushd (I, 1419 H: 136) menyatakan bahwa pengetahuan terkait tanda-tanda peralihan antar darah (haid dan istị̣ạdah), peralihan dari masa suci ke masa haid, dan masa haid ke masa suci didasarkan pada pengetahuan terhadap dua hal, yaitu: pertama, jumlah hari keluar darah menurut kebiasaan; dan kedua, hari-hari suci. Sehingga pembahasan utama dititikberatkan pada persoalan haid terlebih dahulu. Pendapat ini mungkin saja sebagai warisan transmisi keilmuan ketika membahas masalah darah reproduksi perempuan dalam Islam.

Pola pembahasan dari berbagai kitab fiqh tentang hukum darah reproduksi perempuan memang pada umumnya menggunakan paradigma ini. Bahwa titik tolak berawal dari asumsi kesehatan reproduksi perempuan yang ditandai dengan haid yang terjadi secara siklik. Pada paradigma ini, maka permasalahan haid dan segala hal yang terkait menjadi sangat sentral. Baik berupa karakteristik darah yang mencakup warna, kuat-tidaknya aliran darah, bau, dan sebagainya. Begitu pula tentang awal mula menstruasi (menarche), batas waktu minimal dan maksimal haid, serta siklus haid. Sementara pembahasan istīhạdah) tergolong lebih ringkas dibandingkan pembahasan tentang haid. Realitas ini dapat dilihat dari karya Ibn Rushd, Bidāyah al-Mujtahid yang kemudian menguraikan tujuh permasalahan pokok yang mencakup diskusi tentang jumlah hari-hari haid, haid yang terputus-putus, masa nifas, darah yang dilihat perempuan hamil, status hukum cairan berwarna kuning dan keruh atau kelabu, tanda suci dari haid, dan perempuan istị̂ạdah) (Ibn Rushd, I, 1419 H: 137-146). Sistematika ini terus berlangsung hingga penulisan kitab-kitab fiqh pada masa-masa berikutnya.

Minimnya pembahasan tentang istị̣ạdah) dapat dilihat misalnya dari karya al-Jazīrī (I, 2003: 119-120), al-Fiqh 'alā Madhāhib al-Arba'ah yang secara singkat mendefinisikan istiḥạd ab) sebagai berikut: 
“...mengalirnya darah di luar waktu ḥaì dan nifäs dari rahim. Maka setiap yang melebihi batas maksimal haid atau kurang dari batas minimalnya, atau mengalir sebelum usia haid, maka disebut Istị̧ädah. Tidak disyaratkan pada keluar darah Istị̆ädah bagi perempuan yang telah mencapai usia haid. Bahkan jika keluar darah dari anak perempuan kecil yang usianya kurang dari sembilan atau tujuh tahun, maka disebut darah Istị̄ạdah."

Dikatakan singkat, karena untuk definisi haid saja, al-Jazīrī (I, 2003: 114-117) merinci pendapat masing-masing mazhab -sebagai karakteristik karya fiqh perbandingan- dengan menjelaskan kata-per-kata dari definisi yang diajukan setiap mazhab.

Sudut pandang untuk melihat status darah pervaginam di dalam Islam dengan menitikberatkan pada konsepsi haid bukan berarti sebuah kekeliruan. Bahkan merupakan indikasi kuat tentang besarnya perhatian sarjana muslim awal tentang masalah haid yang dinyatakan dalam al-Qur'an secara eksplisit pada surah al-Baqarah [2]: 222 dan juga al-Ṭalāq [65]: 4. Ditambah dengan banyaknya hadis Nabi saw. terkait masalah ini.

Ketidaktepatan terjadi pada saat penyimpulan hukum terkait isu darah pervaginam selalu menggunakan paradigma ini. Apalagi ketika dikaitkan dengan perubahan siklus menstruasi yang dialami akseptor KB hormonal. Kekeliruan inipun juga awalnya dialami oleh peneliti yang mencoba melihat realitas perdarahan abnormal pada akseptor KB hormonal dengan paradigma "haid-cum-Istīhädah."

Titik tolak paradigma haid-cum-Istiḥädah adalah dengan mengidentifikasi darah haid terlebih dahulu. Artinya melihat batas minimal darah haid yang keluar. Apabila memenuhi syarat sebagai batas minimal darah haid, maka dinyatakan sebagai haid pada hari pertama. Pendapat mazhab terkait hal ini sangat beragam. Mazhab Mālikī menyatakan dufqah wāḥidah (satu tetes) sudah merupakan haid. Shāfíci dan Hanābilah minimal satu hari satu malam. Sementara Hanafī minimal tiga hari. Setelah penentuan hari pertama haid, maka yang menyebabkan darah itu beralih menjadi Istị̣ạdah ketika melampaui batas maksimal. Pada batas maksimal inipun terjadi perbedaan pendapat. Mazhab Hanafī menyatakan sepuluh hari dan tiga mazhab lainnya selama 15 hari.

Identifikasi darah haid tidak semata dengan melihat batas minimal dan maksimal periode haid. Pertimbangan lainnya berupa karakteristik darah yang dikeluarkan meliputi warna, bau, dan derasnya aliran darah. Pertimbangan ini terkait erat dengan klasifikasi perempuan yang terbagi menjadi tiga, yaitu: mubtadi'ab (menarke: pertama kali haid), mu'täddah 
(perempuan yang memiliki kebiasaan siklus menstruasi), dan mumayyizah (perempuan yang dapat membedakan karakter darahnya).

Paradigma haid-cum-Istiḩạdah diakhiri dengan penelaahan terhadap peralihan masa haid ke masa suci apabila tidak terjadi Istị̧ạdah. Terdapat dua indikator perempuan telah suci, yaitu: pertama, adanya cairan putih yang didorong oleh rahim atau disebut qas sah baydä. Cairan ini dapat berwarna bening, kental seperti adonan, atau seperti sperma; kedua, dengan keringnya atau berhenti darah (al-jufüf). Ibn Rushd (I, 1419 H: 143-144) menjelaskan perbedaan pendapat terkait masalah ini bahwa menurut Ibn Ḥabīb, salah satu murid Imām Mālik menyatakan bahwa kedua indikator tersebut dapat dijadikan patokan tanda suci perempuan. Namun ada pendapat yang disandarkan pada Imām Mālik dalam alMudawwanah dengan cara membedakan kategori perempuan. Jika termasuk sucinya dengan melihat cairan putih, maka tidak suci hingga melihat cairan tersebut. Jika tidak, maka tanda sucinya dengan kering (jufüf). Adapula pendapat yang menyatakan bahwa perempuan yang memiliki kebiasaan jufüf, maka tanda sucinya adalah dengan cairan putih. Tetapi perempuan yang memiliki kebiasaan cairan putih tidak dapat menjadikan jufüf sebagai tanda sucinya. Pendapat berikutnya yang disampaikan Ibn Rushd adalah kebalikan dari pendapat terakhir.

Ada beberapa kelemahan yang terjadi ketika paradigma ini digunakan dalam melihat status hukum darah reproduksi akseptor KB hormonal. Berikut uraian kelemahan tersebut menurut analisis peneliti.

Pertama, kenyataan bahwa darah yang keluar dari akseptor KB hormonal bukanlah hasil peluruhan sel telur yang matang dan tidak terjadi pembuahan oleh spermatozoa berupa deskuamasi endometrium secara siklik. Sel telur pada akseptor KB hormonal tidak pernah mengalami pematangan (anovulatoir). Sementara menurut medis, menstruasi secara umum harus ada sel telur yang dihasilkan terlebih dahulu berupa pengaruh proses hypotalamus, hipofisis yang berakhir pada corpus menstruatum ketika tidak terjadi pembuahan (Wahdi Sdj, Sp.OG, wawancara, 28 September 2019). Definisi ini selaras dengan yang dikemukakan para ahli figh semua mazhab meskipun dengan redaksi yang lebih sederhana. Perpaduan definisi secara medis dan fiqh mengarahkan bahwa darah reproduksi perempuan akseptor KB hormonal tidak dapat disebut menstruasi. 
ljtihad: Jurnal Wacana Hukum Islam dan Kemanusiaan, Volume 19, No. 1, Juni 2019: 103-123

Kedua, paradigma haid-cum-istihạạdah pada akseptor KB hormonal akan mengidentifikasi bahwa perdarahan pertama dinyatakan haid hingga menunggu batas maksimal periode haid antara 10 atau 15 hari. Ketika melewati batas maksimal tersebut, barulah darah tersebut dinyatakan istị̧ạdah. Padahal seperti yang dinyatakan dalam poin sebelumnya, secara medis maupun figh, darah tersebut bukan sebagai darah haid. Penyimpulan hukum haid harus disertai adanya sabab, di mana ketika tidak ditemukan sabab maka tidak berlaku hukum (Setiawan, 2018: 46-47). Implikasinya menjadi serius ketika dihubungkan dengan masalah ibadah terutama salat, puasa, dan thawaf. Begitu juga dalam hukum perkawinan terkait hubungan seksual dan penentuan masa 'iddah. Sesuatu yang wajib dilaksanakan menjadi tidak dilakukan tanpa ada 'udhr shar' (halangan yang dibolehkan syariat).

Ketiga, pada sisi lain, ketika menggunakan paradigma haid-cum-istiḥạdah yang didasarkan pada temuan medis dan penelaahan kitab-kitab fiqh akan membawa pada kesimpulan bahwa semua akseptor KB selalu istị̣ạdah. Sebab darah yang keluar bukan dinyatakan sebagai haid. Kesimpulan ini dimungkinkan karena semua darah dinyatakan bukan hasil peluruhan sel telur yang berujung deskuamasi endometrium. Lebih aneh ketika menetapkan kalau darah yang keluar sebagai haid, sementara flek baik sebelum atau setelah berlalu darah sebagai istih ădah. Sebab semua darah ini statusnya sama. Bagaimana mungkin menetapkan darah yang sama namun hanya berbeda volume atau jumlah keluarnya dengan hukum yang berbeda? Sehingga menurut logika hukum, apabila menggunakan paradigma haid-cum-istiḥädah maka kesimpulan akhirnya bahwa semua akseptor hormonal sebagai perempuan yang istihạd ah. Hal ini menjadi asing dalam ketentuan fiqh perempuan. Bagaimana mungkin seorang perempuan dalam usia subur akibat penggunaan kontrasepsi yang dilakukan dengan sengaja dan masih mendapati darah atau flek setiap bulan dinyatakan istiḥạdah terus menerus?

\section{Paradigma alternatif istiḥädah-cum-haid dalam penetapan hukum darah akseptor KB hormonal}

Berdasarkan kelemahan paradigma tersebut, maka artikel ini mengajukan paradigma alternatif yang kemudian disebut sebagai istiḩădah-cum-haid. Paradigma ini meniscayakan penyimpulan hukum terkait darah pervaginam dengan titik tolak pada identifikasi darah istiḥạdah yang kemudian dilanjutkan untuk menetapkan waktu haid bagi perempuan istihädah 
tersebut. Penyimpulan hukum seperti ini dilihat lebih tepat dalam menyelesaikan kasus hukum bagi akseptor KB hormonal yang mengalami gangguan menstruasi. Ada beberapa argumentasi yang dapat dikemukakan, yaitu sebagai berikut:

Pertama, realitas secara medis dan definisi fiqh tentang darah pervaginam akseptor $\mathrm{KB}$ hormonal bukan menstruasi yang umum dikenal memperkuat analisis harus dititikberatkan pada konsep istihạdah. Langkah ini lebih memiliki otoritas hukum disebabkan kemiripan dengan cara yang dilakukan Nabi saw. ketika ditanya para sạ̣äbiyah yang banyak melahirkan hadis-hadis tentang haid dan istị̧ạdah. Hampir semua kasus berawal dari kegelisahan para perempuan yang mengalami perdarahan di luar kebiasaan. Titik tolak penetapan hukum yang diberikan Nabi saw. berawal dari kasus istihạạdah. Jika dihubungkan dengan medis, maka perdarahan inilah yang disebut dengan abnormal uterine bleeding yang menurut konsesi ahli ginekologi dan obstetri, yaitu FIGO (The International Federation of Gynecology and Obstetrics) dapat disebabkan oleh PALM-COEIN (Hendarto, 2011: 20). PALM merupakan alat analisis medis untuk perdarahan abnormal secara anatomik. Sementara COEIN sebagai analisis secara fisiologis atau fungsional, di antaranya kelainan karena pengaruh hormon termasuk penggunaan kontrasepsi hormonal (Wahdi Sdj., Sp. OG., wawancara, 28 September 2019). Pada titik ini terjadi harmonisasi antara ketentuan syariat dan keilmuan medis modern tanpa menegasikan salah satunya. Dalam perspektif usul fiqh, model penyimpulan hukum ini dapat dinyatakan pemaduan antara nalar bayāni yang berbasis teks dengan nalar burhān̄ yang bertumpu pada rasio.

Kedua, kesimpulan hukum dengan mempertimbangkan otoritas teks yang disandingkan hasil penelitian burhānì sebagai komplementer memiliki contoh ulama mazhab seperti Ibn Rushd yang mengakomodir pendapat Galenus dan Hipokrates, dua ahli kedokteran dari Yunani dalam Bidāyat al-Mujtahid ketika membahas masalah perempuan hamil apakah dapat mengalami haid atau tidak.

Ketiga, penyimpulan hukum Islam tidak berarti apa-apa tanpa adanya dukungan teks. Penggunaan hadis-hadis Nabi saw. dalam kasus istị̣ạdah dijadikan pijakan dasar. Dukungan dasarnya berupa penafsiran surah al-Baqarah [2]: 222 yang dihubungkan dengan surah al-Ṭalāq [65]: 4. Pada al-Ṭalāq [65]: 4 ditegaskan apa yang harus dilakukan ketika raguragu terkait perhitungan masa iddah perempuan dengan redaksi in-r-tabtum (jika kalian 
ljtihad: Jurnal Wacana Hukum Islam dan Kemanusiaan, Volume 19, No. 1, Juni 2019: 103-123

ragu-ragu), maka solusi al-Qur'an dengan menetapkan tiga bulan. Cara al-Shāri` (Penetap Hukum Syariat ; Allah swt) dalam kasus ini linear dengan cara Nabi saw. ketika memberikan jawaban terhadap Hamnah binti Jahsh yang meminta kepastian haidnya karena mengalami perdarahan yang sangat banyak (metrorraghea). Solusi dari Nabi saw. dengan memerintahkan untuk haid selama enam atau tujuh hari dengan siklus antara 23 atau 24 hari. Dalam kasus hukum lainnya yang sering dikenal adalah penentuan awal Ramadhan dan Syawwal yang ketika mengalami keraguan, diperintahkan untuk menggenapkan umur bulan menjadi 30 hari. Pola ketetapan syariat inilah yang melahirkan salah satu kaidah dasar hukum Islam yang melahirkan begitu banyak kaidah turunan (Washil and Azzam, terj. Wahyu Setiawan, 2009: 15), yaitu:

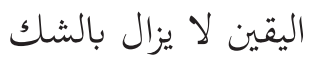

"Keyakinan tidak dapat digugurkan dengan keraguan."

Penggunaan kaidah ini menjadi sangat relevan dalam penetapan status hukum darah perempuan akseptor KB hormonal.

Keempat, paradigma istị̧ạdah-cum-haid tetap mengakomodir, alih-alih mendekonstruksi pemikiran fuqahä' madhahib, terutama terkait konsepsi haid. Bahkan memperkuat analisis dari mazhab Hanafì yang mengkonsepsikan haid tidak semata dari sudut pandang najis tapi juga sebagai Hadath. Maksudnya bahwa pada mazhab ini berbeda dengan tiga mazhab lainnya yang mendefinisikan haid semata sebagai "darah.” Dalam literatur mazhab Hanafi juga dikemukakan oleh al-Jazīrī (I, 2003: 115) pendefinisian haid dalam sudut pandang sebagai Hadath, yaitu:

صفة شرعية توصف بها المرأة بسبب نزول الدم فتحرم وطأها وتمنعها من الصلاة والصيام وغير ذلك "Sifat shar'i yang perempuan disifatkan demikian disebabkan keluarnya darah, maka diharamkan menyetububinya, perempuan tersebut terlarang salat dan puasa, dan sebagainya"

Definisi tersebut membuka ruang bagi penentuan haid dalam masa istiḥặah seperti yang akan dijelaskan dalam paradigma istiḥậ̣ah ah-cum-haid. Pada sisi lain, juga didukung oleh pendapat mazhab Mālikī yang menyatakan jika darah haid keluar disebabkan efek samping obat, maka pendapat yang jelas dari mazhab ini darah tersebut tidak disebut haid. Perempuan wajib salat dan puasa (al-Jazīrī, I, 2003: 115). Pendapat mazhab ini memang 
tidak mengherankan telah mengakomodir penggunaan obat untuk rekayasa siklus haid, sebab berbeda dari mazhab lainnya, pada mazhab Mālikī banyak ulama yang berbasis ahli kedokteran seperti Ibn Rushd. Berdasarkan pendapat mazhab ini, cara penentuan darah akseptor KB hormonal pada dasarnya bukan sesuatu yang asing dalam wacana figh mazhab. Melalui paradigma istihăạdah-cum-haid, maka tercapai prinsip penyimpulan hukum:

$$
\text { المحافظة للقديم الصالح والأخذ بالجديد الأصلح }
$$

"Memelihara (pendapat) terdahulu yang baik dan mengambil sesuatu yang baru yang terbaik."

\section{Aplikasi penyimpulan hukum dengan paradigma istiḩạdah-cum-haid}

Langkah awal yang dilakukan peneliti dengan menginventarisir hadis-hadis di seputar kasus istihạạdah. Paling tidak, ada tiga hadis utama yang dijadikan sandaran ulama mazhab dalam menetapkan hukum darah bagi perempuan istihäạdah. Ketiga hadis tersebut dapat dilihat di bawah ini.

\begin{tabular}{|c|c|c|c|}
\hline No. & Kasus & Bunyi Hadis & Keterangan \\
\hline 1. & $\begin{array}{l}\text { Hadis Aisyah pada } \\
\text { Kasus Fatīmah binti } \\
\text { Abī Hubaish }\end{array}$ & 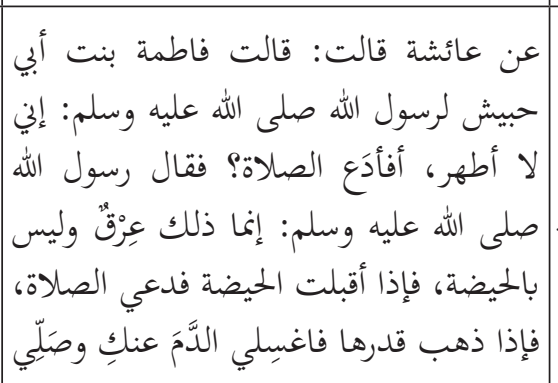 & $\begin{array}{l}\text { Kasus istihäạdah. } \\
\text { Solusi Nabi saw.: itu adalah 'irq } \\
\text { bukan haidh. Apabila tiba masa } \\
\text { haid, baru tinggalkan shalat. } \\
\text { Jika berhenti, basuh darah dan } \\
\text { shalat. Dalam riwayat lain: } \\
\text { berwudhu setiap akan shalat }\end{array}$ \\
\hline 2. & $\begin{array}{l}\text { Hadis Ummu } \\
\text { Salamah }\end{array}$ & 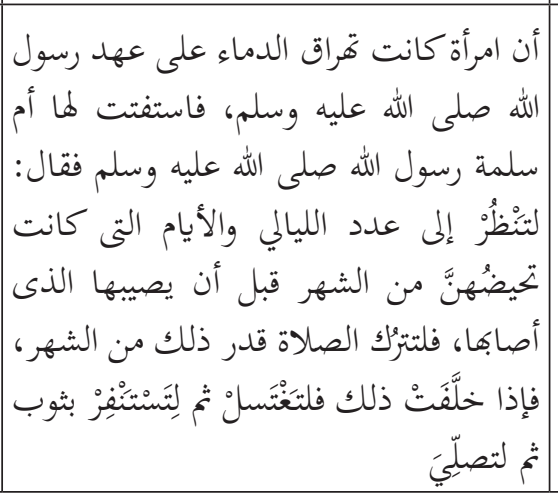 & $\begin{array}{l}\text { Kasus istihäạah. } \\
\text { Solusi Nabi saw. untuk } \\
\text { melaksanakan haid sejumlah } \\
\text { hari sebelum terjadi } \\
\text { istihădah menurut kebiasaan } \\
\text { setiap bulannya. }\end{array}$ \\
\hline
\end{tabular}


ljtihad: Jurnal Wacana Hukum Islam dan Kemanusiaan, Volume 19, No. 1, Juni 2019: 103-123

\begin{tabular}{|c|c|c|c|}
\hline No. & Kasus & Bunyi Hadis & Keterangan \\
\hline 3. & $\begin{array}{l}\text { Kasus Tamnah binti } \\
\text { Jahsh }\end{array}$ & فأ & $\begin{array}{l}\text { Kasus Istihäadah } \\
\text { Solusi Nabi saw. untuk } \\
\text { menghitung haid antara 6-7 hari } \\
\text { dengan siklus haid antara } 23 \\
\text { atau } 24 \text { hari. }\end{array}$ \\
\hline
\end{tabular}

Setelah melihat ketiga hadis tersebut, peneliti lebih memilih cara al-Shāfíi dalam alUmm yang memperlakukan ketiga hadis tersebut dengan metode al-jam' wa al-tawfiq (penggabungan dan sinkronisasi). Al-jam'u wa al-tawfíg merupakan salah satu metode dari tiga metode dalam kajian ushul fiqh ketika ada dalil-dalil yang terlihat bertentangan. Selain 
al-jam' wa al-tawfiq alternatif yang digunakan adalah metode naskb (menghapus ketentuan hukum terdahulu dan menetapkan hukum yang datang belakangan: ketentuan hukum terbaru) dan tarjī (menguatkan satu dalil dan melemahkan dalil lainnya) (Setiawan, 2018: 92-92). Penggunaan pendapat al-Shāfíī juga mempertimbangkan bahwa dalam praktik keagamaan muslim Indonesia lebih banyak berafiliasi pada mazhab Shāfi ī. Walaupun tidak ada data otentik untuk klaim ini.

Al-Shāfīi (II, 2001: 135) mendasari pemahaman bahwa tiga hadis, yaitu: hadis 'A 'A'ishah, Hamnah binti Jahsh, dan Ummu Salamah tidak saling kontradiktif dan dapat dilakukan sinkronisasi. Sebagian hadis berposisi zivädah (keterangan tambahan) sehingga memunculkan makna yang melengkapi makna hadis lainnya. Berikut pemaduan yang dilakukan al-Shāfíī terhadap ketiga kasus yang dimunculkan pada masa Nabi saw. tersebut.

Pertama, hadis 'Ā'ishah menunjukkan bahwa pada kasus Fạtimah binti Abī Ḥubaysh darah istihäạah-nya terpisah dari darah haid. Indikasi ini dilihat dari jawaban Nabi saw:

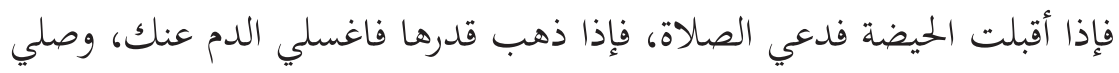

"Apabila darah haid muncul maka tinggalkan salat, apabila telah pergi ukurannya maka basublah darah, dan salat."

Dari sisi ini, al-Shāficị (II, 2001: 135) berpendapat jika darah yang keluar memiliki ciri berbeda, pada beberapa hari warna merah kehitaman dan kemudian pada beberapa hari lainnya lebih muda mendekati kekuningan atau semakin sedikit. Maka hari-hari keluar darah merah kental sebagai hari haid, dan selainnya sebagai istihădah.

Kedua, jawaban yang diberikan Nabi saw kepada Ummu Salamah terkait kasus perempuan istibăạdah menunjukkan bahwa perempuan yang bertanya kepada Ummu Salamah tidak terjadi pemilahan darah. Maksudnya darah yang keluar tidak dapat dibedakan karakteristiknya. Nabi saw memerintahkannya untuk meninggalkan salat sejumlah malam dan hari ketika ia haid dalam sebulan, seperti kebiasaan sebelum mengalami istihäạah. Berdasarkan kasus ini, maka menurut al-Shāfíîi (II, 2001: 136), pada kasus serupa maka masa haid perempuan mengikuti pada kebiasaan sebelumnya. Hadis Ummu Salamah ini dapat dihubungkan dengan hadis Hamnah binti Jahsh.

Ketiga, hadis Ḥamnah menurut al-Shāfíīi (II, 2001: 137) mengandung makna bahwa pada dasarnya ia telah mengetahui masa haidnya sebelum terjadi istihäădah, yaitu antara enam 
hingga tujuh hari. Sehingga hadis Hamnah pada sisi lain dapat diterapkan juga pada kasus perempuan istiḩạdah yang tidak dapat memilah karakteristik darah dan tidak mempunyai kebiasaan masa haid sebelumnya. Tidak memiliki siklus haid dapat terjadi karena memang sebelumnya haid yang dialami tidak memiliki keteraturan atau disebabkan menarke, yaitu haid yang terjadi untuk pertama kali.

Penggunaan hadis pada kasus Hamnah dengan kesimpulan seperti ini dapat dilihat dari pendapat al-Shāfíī tentang kasus menarke (perempuan untuk pertama kali haid) yang langsung istị̧ạdah. Apabila ada perbedaan karakteristik darah (munfasì), maka seperti hadis ' $\bar{A}$ 'ishah, darah merah kehitaman sebagai haid dan darah yang lebih ringan sebagai istị̣ādah. Jika tidak ada perbedaan karakteristik darah, maka ada dua pendapat: pertama, meninggalkan salat enam atau tujuh hari, kemudian mandi, salat, sebagaimana perempuan umumnya haid. Pendapat ini bertumpu pada hadis Hamnah binti Jahsh; kedua, meninggalkan salat pada batas minimal haid, yaitu satu hari satu malam, kemudian mandi dan salat, bagi suaminya boleh melakukan hubungan seksual. Namun jika kemudian lebih memilih berhati-hati, yaitu dengan meninggalkan salat selama setengah atau lebih dari masa haid umumnya, merupakan pendapat yang lebih disukai al-Shāficì (II, 2001: 136).

Berdasarkan pendapat al-Shāficī tersebut, maka penentuan hukum darah pervaginam pada akseptor KB dapat dilakukan dengan ketiga cara tersebut. Bagi akseptor KB yang dapat membedakan karakter darah yang keluar, maka dapat menentukan masa haidnya melalui pengetahuan tamyiz (membedakan) tersebut. Sebab pada dasarnya, darah haid dikenali oleh para wanita. Pendapat ini bertumpu pada hadis 'A' 'ishah tentang kasus Fātimah binti Abī Hubaysh. Bagi perempuan yang sebelum menggunakan alat kontrasepsi hormonal telah memiliki siklus teratur, maka penentuan haidnya berdasar pada siklus tersebut. Ketentuan ini didasarkan pada solusi Nabi saw. pada hadis Ummu Salamah. Sedangkan perempuan yang pada satu sisi tidak dapat membedakan karakteristik darah, baik karena keragu-raguan atau sebab lainnya, sementara di sisi lain tidak memiliki siklus menstruasi yang teratur sebelum penggunaan alat kontrasepsi, maka penentuan haidnya dengan menetapkan antara enam atau tujuh hari dengan panjang siklus menstruasi antara 23 atau 24 hari. Landasan argumentasi ketentuan ini berdasar pada hadis dengan kasus Hamnah binti Jahsh. 
Telaah ulang wacana haid dan istiḥạ̄ah pada akseptor keluarga berencana (Wahyu Setiawan, dkk.)

\section{Penutup}

Kejadian umum yang dialami akseptor KB hormonal adalah adanya spoting dengan jumlah hari yang beragam pada akseptor dan bersifat kasuistik. Selain itu, gangguan menstruasi juga terjadi dalam bentuk bipomenorrhea (hari tetap-darah lebih sedikit), bipermenorrhea (hari tetapdarah lebih banyak), menorraghea (hari bertambah-darah banyak), metrorraghea (darah banyakdi luar siklus), dan meno-metrorraghea (jeda hari -darah banyak). Paradigma yang ditawarkan sebagai alternatif penetapan darah pervaginam akseptor KB disebut dengan paradigma istihäădah-cum-haid. Paradigma ini dengan melihat kondisi obyektif darah itu sendiri. Darah yang keluar, baik spoting atau bentuk perdarahan lainnya yang disebabkan penggunaan KB hormonal bukanlah hasil peluruhan sel telur yang matang dan tidak terjadi pembuahan oleh spermatozoa. Sel telur pada akseptor KB hormonal tidak pernah mengalami pematangan (anovulatoir). Definisi ini selaras dengan yang dikemukakan para ahli fiqh semua mazhab meskipun dengan redaksi yang lebih sederhana. Perpaduan definisi secara medis dan fiqh mengarahkan bahwa darah pervaginam akseptor $\mathrm{KB}$ hormonal dapat disebut sebagai istihăạdah, bukan sebagai haid. Kemudian dilanjutkan untuk menetapkan waktu haid bagi perempuan istihäadah tersebut.

Akhirnya, bahwa upaya menghadirkan ketentuan hukum secara tekstual terhadap pemikiran abad pertengahan tanpa daya kritis akan terjebak pada sakralitas pemikiran Islam. Begitu juga dekonstruksi pemikiran mazhab, sering terperangkap pada aspek legalitas dan justifikasi. Banyak aspek pemikiran fuqahä’ yang dapat diintrodusir dalam menyelesaikan berbagai permasalahan hukum Islam kontemporer. Integrasi keilmuan seperti antara medis dan hukum Islam dengan melihat realitas yang dialami subyek hukum merupakan sebuah pilihan. Upaya menghubungkan antara nalar bayānì, burbānì, dan pengalaman empiris manusia membuat produk hukum Islam menjadi lebih aplikatif tanpa tercerabut dari akar hukum itu sendiri sebagai titah ilahi (khitäbulläh).

\section{Daftar pustaka}

Abdullah et al. "Blood Women in Perspective of Fiqh Syafi'iyyah and Medical Science." Britain International of Humanities and Social Sciences (BIoHS) Journal, 1(2), 2019. doi: 10.33258/biohs.v1i2.27. 
ljtihad: Jurnal Wacana Hukum Islam dan Kemanusiaan, Volume 19, No. 1, Juni 2019: 103-123

Anwar, Syamsul. "Ke Arah Epistemologi Integratif Mencari Arah Pengembangan Keilmuan dalam Rangka Pemekaran IAIN.” Dalam Menyatukan Kembali Ilmu-ilmu Agama dan Umum. Yogyakarta: Suka Press, 2003.

Barakah, Ainun. "Istihadhah Dan Problematikanya Dalam Kehidupan Praktis Masyarakat." Jurnal Cendekia, 1 (1), 2018.

Baziad, Ali. Kontrasepsi Hormonal. Jakarta: YBP-SP, 2002.

Hendarto, Hendy. "Implikasi Klinis PALM COEIN terhadap Penatalaksanaan Perdarahan Uterus Abnormal." Dalam Astarto, N. W. dkk (ed.). Kupas Tuntas Kelainan Haid. Jakarta: Sagung Seto, 2011.

Ibn Rushd, Muḥammad ibn Aḥmad ibn Muḥammad ibn Aḥmad. Bidāyah al-Mujtahid wa Nihāyah al-Muqtasid. Madinah: Dār al-Khuḍayrī, 1419 H.

Ibrahim, Basri Bin. "Amalan Pengurusan Bersuci Darah-Darah Wanita Menurut Perspektif Islam.” Jurnal Islam dan Masyarakat Kontemporari, 13(2), 2016.

al-Jazīrī, 'Abdurraḥmān. Kitāb al-Fiqh 'alā al-Madhāhib al-Arba'ah. Beirut: Dār al-Kutub al'Ilmiyah, 2003.

Mahdalena, N., Prihatin, T. W. and Rahayu, H. "Hubungan Lamanya Penggunaan Kb Suntik 3 Bulan Terhadap Perubahan Siklus Menstruasi Di Bps Ny. S Desa Sambirejo, Semarang." Prosiding Seminar Nasional \& Internasional, 2(1), 2014.

Metro, BPS Kota. Kota Metro dalam Angka 2018. Metro: BPS Kota Metro, 2018.

Misbah, Muhammad. "Hadits Mukhtalif dan Pengaruhnya terhadap Hukum Fikih: Studi Kasus Haid dalam Kitab Bidayatul Mujtahid.” Riwayah : Jurnal Studi Hadis, 2(1), 2017. Musyafa'ah, Nur Lailatul. "Rekonstruksi Fiqh Pendarahan Pervaginam dengan Pendekatan Medis.” ISLAMICA: Jurnal Studi Keislaman, 8(1), 2014.

Musyafa'ah, Nur Lailatul. 'Relevansi Antara Medis Dan Fikih Tentang Perdarahan Pervaginam', Gender Indonesia, 05(2), 2016.

al-Nawawī. al-Majmū'Syarḥ al-Muhadhdhab. Beirut: Dār al-Fikr, tt.

al-Shāfìī, Muḥammad ibn Idrīs. Al-Umm. ttp.: Dār al-Wafā’, 2001.

Noble, Molly. "Religiosity and Feminism: Navigating Gender Constructions and Ideologies." (2018). https:// digitalcommons.bumboldt.edu.. 
Telaah ulang wacana haid dan istiḥāḍah pada akseptor keluarga berencana (Wahyu Setiawan, dkk.)

Olusola, A. I. dan M. Y. Ojo. "Patriarchal Ideologies on Women's Menstrual Cycle: an Infringement on the Rights of Women.” IJHCS Vol. 1, Issue 2, September 2014.

Safi, Louay. The Foundation of Knowledge, A Comparative Study in Islamic and western Methods of Inquiry. Selangor: International Islamic University Malaysia Press, 1996.

Setiawan, Wahyu. Perbandingan Maz̧hab Ushul: Sebuah Pengantar. Yogyakarta: Idea Press, 2018. Sigvartsen, Jan A. “The Biblical Law of Niddah and Its Muslim Parallels." (2017), Papers 8, https:// digitalcommons.andrews.edu/papers/8..

Washil, Nasr Farid Muhammad dan Abdul Aziz Muhammad Azzam. Qawa’id Fiqhiyyah. Terjemah Wahyu Setiawan. Jakarta: Amzah, 2009. 
